\title{
Effects of Alien Plants on Ecosystem Structure and Functioning and Implications for Restoration: Insights from Three Degraded Sites in South African Fynbos
}

\author{
Mirijam Gaertner • David M. Richardson • \\ Sean D. J. Privett
}

Received: 19 January 2010/Accepted: 3 April 2011/Published online: 26 April 2011

(C) Springer Science+Business Media, LLC 2011

\begin{abstract}
We investigated the type and extent of degradation at three sites on the Agulhas Plain, South Africa: an old field dominated by the alien grass Pennisetum clandestinum Pers. (kikuyu), an abandoned Eucalyptus plantation, and a natural fynbos community invaded by nitrogen fixing-Australian Acacia species. These forms of degradation are representative of many areas in the region. By identifying the nature and degree of ecosystem degradation we aimed to determine appropriate strategies for restoration in this biodiversity hotspot. Vegetation surveys were conducted at degraded sites and carefully selected reference sites. Soil-stored propagule seed banks and macro- and micro-soil nutrients were determined. Species richness, diversity and native cover under Eucalyptus were extremely low compared to the reference site and alterations of the soil nutrients were the most severe. The cover of indigenous species under Acacia did not differ significantly from that in reference sites, but species richness was lower under Acacia and soils were considerably enriched. Native species richness was much lower in the kikuyu site, but soil nutrient status was similar to the reference site. Removal of the alien species alone may be sufficient to re-initiate ecosystem recovery at the kikuyu site, whereas active restoration is required to restore functioning ecosystems dominated by native species in the Acacia thicket and the Eucalyptus plantation. To restore native plant communities we suggest
\end{abstract}

M. Gaertner $(\bowtie)$. D. M. Richardson

Centre for Invasion Biology, Department of Botany \& Zoology, Stellenbosch University, Private Bag X1, Matieland 7602,

South Africa

e-mail: gaertnem@gmail.com

S. D. J. Privett

Flower Valley Conservation Trust, PO Box 393,

Gansbaai 7220, South Africa burning, mulching with sawdust and sowing of native species.

Keywords Biological invasions - Degradation - Invasive species · Nutrient enrichment $\cdot$ Rehabilitation

\section{Introduction}

Ecosystem degradation is one of the most fundamental and persistent environmental challenges worldwide (Plieninger and Gaertner 2011). Although biological invasions are undoubtedly a major cause of ecosystem degradation, alien invaders are also often "passengers" of other environmental changes, such as altered disturbance regimes and climate change or human disturbances (Gurevitch and Padilla 2004; MacDougall and Turkington 2005; Chabrerie and others 2010). Invasions frequently occur on abandoned agricultural lands (old fields) (Meiners and other 2002) or in alien tree plantations (Richardson 1998). The fact that invasions are associated with other disturbances complicates the task of separating the effects of alien species on the native ecosystems from the effects of the disturbance that lead to the initial plant invasion.

Ecological restoration has emerged as an important response for tackling ongoing ecosystem degradation (Brudvig 2011). To restore a degraded ecosystem it is important to diagnose the type (nature) and extent of the damage. Next, it needs to be determined whether the ecosystem could recover unaided (Hobbs 2007). If unaided recovery is unlikely, appropriate restoration strategies are required.

The mediterranean biome is one of the most imperiled of the world's biomes (Underwood and others 2009). Besides urbanization and agricultural use (Underwood and others 2009), biological invasions are a major threat to biodiversity 
(Rouget and others 2003; Seabloom and others 2006). Invasive species have many types of impacts on native ecosystems. At the level of populations or communities they can alter community structure and composition (Gaertner and others 2009; Hejda and others 2009). At ecosystem level invasions can alter nutrient cycling (Yelenik and others 2004; Marchante and others 2008) or soil microbial communities (Marchante and others 2007).

Among the world's mediterranean-type ecosystems (MTEs), those in South Africa's Cape Floristic Region (CFR) stand out as being the most affected by declines of native species richness due to alien woody plants (Gaertner and others 2009). Fynbos ecosystems in the CFR have some of the most nutrient-poor soils of all of the world's MTEs and heathlands (Musil and Midgley 1990); they are highly susceptible to soil enrichment due to invasion by nitrogen-fixing alien species. Soil enrichment may change the competitive relationship in favor of invasive alien species, which may outcompete native species. With continuing invasion, native species richness declines as few competitive species become dominant, resulting in the replacement of diverse communities by homogenous, low-diversity communities (Musil 1993).

The objective of this study was to investigate the type and extent of ecosystem degradation on three different types of degraded sites typical of lowland landscapes in the Cape Floristic Region: an old field dominated by the alien grass Pennisetum clandestinum Pers. (kikuyu), an abandoned Eucalyptus plantation, and a natural fynbos shrubland invaded by nitrogen fixing-Australian Acacia species. We identified the type and degree of ecosystem degradation and propose appropriate strategies for ecosystem restoration.

To determine the extent of ecosystem degradation we investigated (1) above-ground vegetation (2) soil seed banks and (3) physical and chemical soil properties in degraded sites compared to native reference sites. At the three sites we hypothesized that the nature and degree of degradation would be related to the growth form and functional characteristics of the dominant alien plants. We expected reduced native species richness and cover and elevated nutrient levels in the Acacia site. In the Eucalyptus plantation we hypothesized less influence of soil nutrient levels, but a marked reduction in native plant species diversity. At the Pennisetum clandestinum site we predicted a competitive advantage over fynbos species but no significant changes in soil nutrient levels.

\section{Methods}

Study Site

The Agulhas Plain occurs at the southern tip of Africa and forms part of the Cape Floristic Region (CFR) which is home to one of the highest concentrations of plant species in the world. The predominant vegetation type in the CFR is fynbos, a sclerophyllous shrubland on nutrient-poor substrata. The Agulhas Plain is a globally significant repository of biodiversity, recognized for its high irreplaceability and vulnerability and has been identified as being of extreme conservation importance (Privett and others 2002). Thousands of hectares of natural vegetation in the CFR have been degraded through agricultural and urban development and inappropriate management practices (Rebelo 1992). Invasive alien plants (especially nitrogen-fixing Acacia species from Australia) are another major threat to biodiversity in remaining untransformed fynbos (Rouget and others 2003). Eucalyptus species are widely planted in the area for a variety of purposes and some species have become invasive (Forsyth and others 2004). Stands of eucalypts may also impact native species richness (Ruthrof and others 2003; Viana and others 2003). The area is also characterized by large abandoned agricultural fields which are often invaded by alien grass species. Alien grasses are a major concern, especially because of their capacity to alter natural fire regimes (Brooks and others 2004; Milton 2004).

The study was conducted on the Flower Valley Farm near Gansbaai on the western side of the Agulhas Plain, about $175 \mathrm{~km}$ east of Cape Town. The farm belongs to a private nature conservation trust and the recent history of the area is well known. The area is centered at $34^{\circ} 32.374 \mathrm{~S} ; 19^{\circ} 28.289 \mathrm{E}$ and has a Mediterranean-type climate with a mean annual rainfall of $500 \mathrm{~mm}$. Monthly rainfall in the study area ranged between $59 \mathrm{~mm}$ and $159 \mathrm{~mm}$ during the investigations; with highest rainfall in November and lowest rainfall in January. The vegetation of Flower Valley Farm is predominantly fynbos, with a small patch of Afromontane forest. The fynbos is largely classified as Overberg Sandstone Fynbos according to Mucina and Rutherford (2006). Large patches of the farm have been invaded by several species of Australian trees: Acacia species (A. cyclops Cunn. ex. G. Don., A. longifolia (Andr.) Willd., A. mearnsii Benth, and A. saligna Cunn. ex. G. Don.), Leptospermum laevigatum (Gaertn.) F. Muell, and Paraserianthes lophantha (Willd.) I.C. Nielson. A woodlot of approximately one hectare was planted with Eucalyptus species (E. conferruminata D. J. Carr and S.G.M. Carr [previously known as E. lehmannii in South Africa], E. cladocalyx F. Muell. and E. gomphocephala A.D.C.). All these eucalypts are known to be invasive, but their impact at this site is mainly in areas where they were planted. The East African grass Pennisetum clandestinum Pers. (kikuyu), which has been planted widely in the region and is rapidly invading disturbed areas, occurs mainly on abandoned fields on the farm. At Flower Valley, as in many other parts of the 
Agulhas Plain, removal of alien plants is a priority in areas earmarked for biodiversity conservation.

\section{Study Design}

We investigated two degraded sites on acidic Table Mountain sandstone: an abandoned Eucalyptus plantation, dominated by E. cladocalyx (Eucalyptus plantation) and a dense Acacia thicket, mainly A. saligna interspersed with A. cyclops. The third site was an old field on neutral deep sands (Overberg dune strandveld) dominated by Pennisetum clandestinum (kikuyu field). All degraded sites had to be dominated by alien species $(80 \%-100 \%$ cover), and a pristine reference site with similar site conditions had to be in close proximity. The kikuyu field measures 0.85 ha (coordinates $34^{\circ} 32^{\prime \prime} 46.59^{\prime} \mathrm{S} ; 1^{\circ} 28^{\prime \prime} 16.98^{\prime} \mathrm{E}$ ). It was a potato field from about the 1930s until the mid 1980s; before planting potatoes the fynbos was cleared by deep ploughing. Eucalyptus trees were planted in the 1940s for timber production on a site that was previously used for subsistence farming (grazing and vegetable gardening) for approximately 10 years. Today the Eucalyptus plantation covers 1.2 ha and forms a heterogeneous mixture of $E$. conferruminata, E. cladocalyx and E. gomphocephala, interspersed with some Acacia saligna and Paraserianthes lophantha (coordinates $34^{\circ} 32^{\prime \prime} 53.88^{\prime} \mathrm{S} ; 1^{\circ} 27^{\prime \prime} 41.17^{\prime} \mathrm{E}$ ). The Acacia site was invaded within the last 15-20 years. It covers 0.5 ha and was not disturbed prior to invasion (coordinates $34^{\circ} 33^{\prime \prime} 16.41^{\prime} \mathrm{S} ; 1^{\circ} 27^{\prime \prime} 38.95^{\prime} \mathrm{E}$ ). For each site we selected an intact natural ("reference") community with the same elevation, slope aspect and slope inclination, soil type and soil $\mathrm{pH}$, no further than $50 \mathrm{~m}$ from the degraded site (Fig. 1). Both the kikuyu field and Eucalyptus plantation and their reference sites burned in February 2006 in a natural fire. The Acacia thicket and its reference site burned in January 2005, also in a natural fire.

Because the history of all study sites (degraded sites and reference sites) has been well documented for the past 70 years we could confirm that important factors that could influence vegetation structure were the same for degraded and reference sites. For example, because the flower farm is remotely situated in a rural region of high conservation value, surrounded by privately owned nature reserves with intact fynbos vegetation, all sites are far removed from any potential sources of nitrogen addition and fertilization. There are also no known sources of atmospheric nitrogen deposition near the study sites. Ideally, vegetation characteristics and soil properties would have been measured before and after conversion to alien species, so we could distinguish between the effects of disturbance prior to invasion and the effects of the alien plants, but that was not possible.
In each of the alien-dominated and reference sites we established three plots $(n=3)$ each measuring 0.04 ha, each with nine subplots measuring $5 \times 5 \mathrm{~m}$ arranged in a grid. We acknowledge that we do not have true replicates of sites, but the use of large contiguous areas means that potential effects of pseudo-replication are minimized.

\section{Vegetation Sampling}

To examine the current state of species composition on degraded sites and their reference sites, full vegetation surveys were conducted in the autumn of 2007 (April and May). In each subplot (162 plots in total) we recorded structural parameters, such as proportion of open soil and litter cover, total projected plant cover and projected canopy cover of the growth forms. We distinguished between growth forms: native graminoids, geophytes, herbs and succulents, and native woody species including ericoids, proteoids, other shrubs (all native shrubs excluding Ericaceae and Proteaceae) and alien graminoids and trees. We also listed all species within the subplots and estimated canopy percent cover. Voucher specimens of all unknown species were collected, pressed and identified to species level where possible. Follow-up field visits to collect additional material of unidentified species took place every second month for 1 year. Nomenclature followed Goldblatt and Manning (2000).

\section{Seed Bank Analysis}

Soil samples for seed bank determination were collected at all six sites in May 2007. Five subplots in each plot were sampled ( $n=15$ per site). Each soil sample comprised five scoops taken with a $10-\mathrm{cm}$ deep and $5-\mathrm{cm}$ diameter soil core. Soil-stored propagules were estimated using the seedling emergence approach (details in Holmes 2002). Soil was air dried and sieved to remove large stones and roots. The samples were stored in paper bags until further processing. In June 2007 (winter) soil samples were transferred to 150 flat seedling trays $\left(16 \mathrm{~cm}^{2}\right)$ containing a layer of sterile sand and given smoke treatment (Brown and Botha 2004). Most fynbos species germinate in winter. Three control trays containing only river sand were prepared to check for dispersal contaminants. After $1 \mathrm{~h}$ smoke-treatment seedling trays were transferred to benches in an open-sided nursery with a shade cloth roof, and watered. Trays were kept moist using an irrigation system. Seedlings began to emerge after one week. They were marked with toothpicks and counted every fortnight. The seedlings were grown until flowering or until they could be identified to genus level. By December 2007 no further germination was noted and the trial was terminated. 

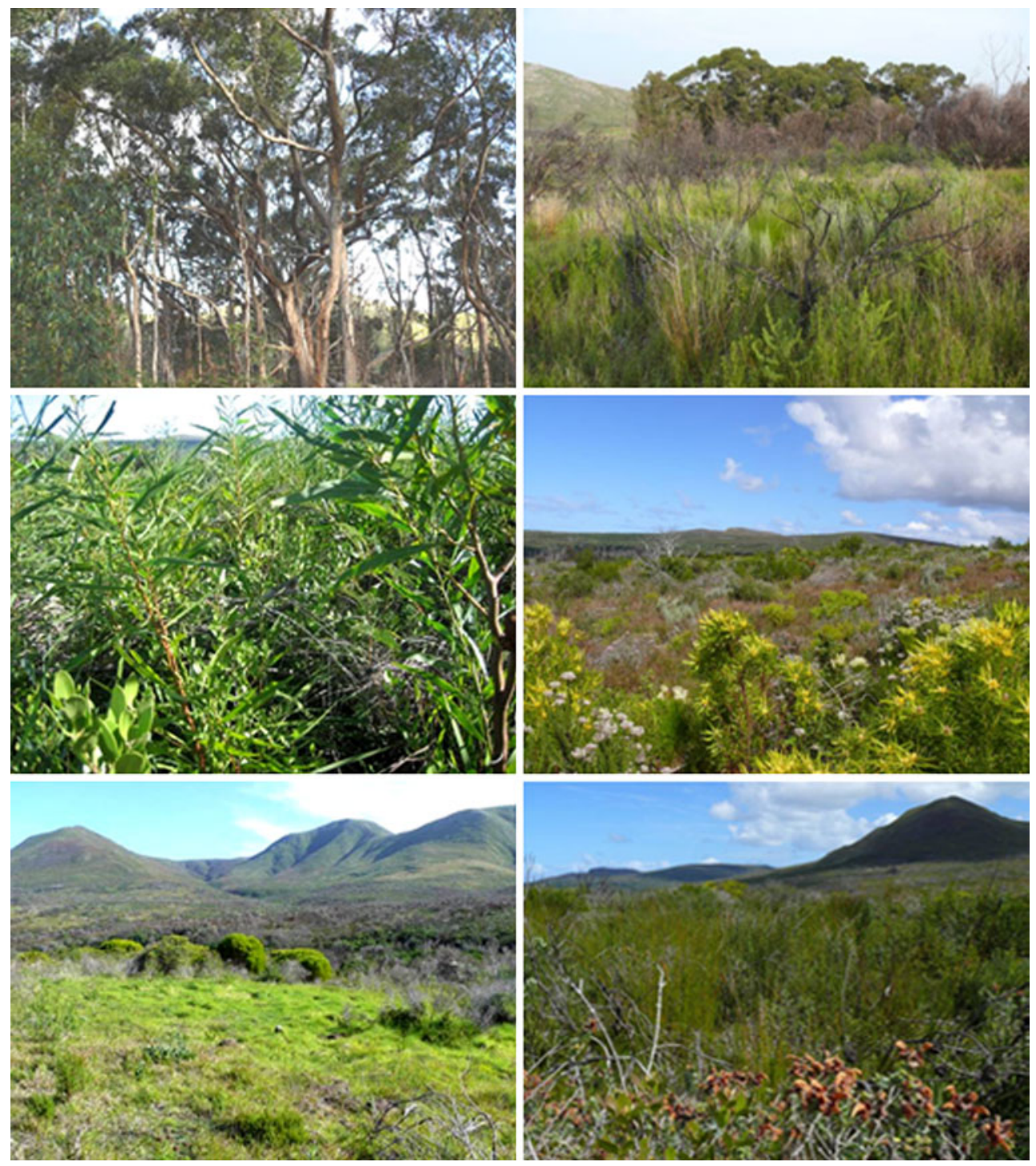

Fig. 1 Study sites at Flower Valley farm, Gansbaai, South Africa. Sites dominated by alien species appear on the left, and matched reference sites on the right. Top Eucalyptus plantation and mountain fynbos on acidic Table Mountain sandstone. Middle Acacia thicket

and mountain fynbos on acidic Table Mountain sandstone. Bottom Pennisetum clandestinum (kikuyu) field and fynbos community on neutral deep sand, Photos: Brummer Olivier

\section{Soil Analysis}

Soil samples for analysis of total nitrogen $(\mathrm{N})$ and phosphorus (P), Carbon (C), Sodium (Na), Magnesium (Mg), Calcium $(\mathrm{Ca})$ and Potassium $(\mathrm{K})$ and ph, were taken randomly in August 2007 with a 10-cm deep and 5-cm diameter soil core in each subplot in all six sites $(n=162)$. Each soil sample comprised five scoops which were combined in a bulk sample. Analysis was done by a commercial laboratory (Bemlab Pty Ltd., Somerset West). We also estimated plant available $\mathrm{N}$ using ion exchange resin bags. The use of in situ ion-exchange resin bags is a repeatable method to measure soil-nutrient availability which does not involve considerable disturbance of the soil profile (Gibson

1986). Resin bags were manufactured from fine polyester standard mesh, measuring $5 \mathrm{~cm}^{2}$ and filled with $5 \mathrm{~g}$ of wet resin (IR $120 \mathrm{Na}$ for ammonium and 4400CL for nitrate, Aquaplan cc, Gauteng, South Africa). Holes were dug in the centre of each subplot, and a spatula was used to lift the soil at the side of the hole to create a slot for the bags. In this way one anion and one cation resin bag were placed next to each other beneath $5 \mathrm{~cm}$ of relatively undisturbed soil. These were removed after two months, placed into clean plastic bags and replaced with the newly regenerated resin bags. Resin bags were put into the soil in the middle of the South African winter (August 2007) and were replaced twice: in October 2007 (spring) and in December 2007 and February 2008 (summer). Resin bags depend on 
water for transferring ions from the soil to the resin; to include seasonal fluctuations resin bags were used over a period of six month including winter rainfall season and the summer dry season. Once removed, the resin bags were eluted in the laboratory. The bags were cleaned by washing dirt and rinsing with distilled water. Each bag was then shaken separately with $50 \mathrm{ml}$ of $5 \% \mathrm{HCl}$ for $30 \mathrm{~min}$. The eluates were placed in glass vials for ammonium and nitrate analysis at Bemlab (Edms) Bpk (Somerset West, South Africa).

To measure soil temperature and relative humidity we used i-buttons (computer chips enclosed in a stainless steel can from Hygrochron, Fairbridge Technologies). We planted one i-button per site $5 \mathrm{~cm}$ deep into the soil for a period of 170 days. Because of the heterogeneity of the site two i-buttons were used in the Eucalyptus plantation. From August 2007 until January 2008 temperature and moisture were measured in one hour intervals.

\section{Statistical Analysis}

Before analysis, data from the nine subplots of each plot were averaged to avoid pseudo-replication. Because of their heterogeneity in elevation, soil type and history the three alien dominated sites (with their native reference sites) are considered as three different experiments. The plots in the sites are defined as experimental units $(n=3)$. For statistical analysis we used the following software: STATISTICA (version 9), Primer (version 5), Estimate SWin 800 and R (version 2.8.1). Count data was $\ln$ transformed to correct normality and homoscedasticity; square root (arcsine) transformation was applied for percentage data.

To describe vegetation structure and composition we analyzed species richness, diversity and evenness (using Shannon-Wiener diversity index). Dominance of growth forms and species was determined using relative importance values based on canopy percent cover. Significant difference between alien-dominated and references sites in species richness and native cover was tested using t-test for independent samples. Difference in diversity and evenness between sites was tested using one-way analysis of variance (ANOVA).

Similarity in species composition was determined using Bray-Curtis similarity index and non-metrical multidimensional scaling (NMDS). We used absolute numbers (total species cover), which is the most commonly used method for multivariate similarity analysis. Before calculation of Bray-Curtis similarity data were transformed. Data transformation is necessary as Bray Curtis similarity does not incorporate any form of scaling of each species by its total or maximum across all samples. The more severe the initial transformation, the more notice is taken of the less abundant species in the matrix. We chose square root transformation which has the effect of down-weighting the importance of highly abundant species, at the same time giving rare species less influence (Clarke and Warwick 2001). NMDS was performed running 50 iterations (restarts) with a minimum stress value of 0.01 .

Mean differences in soil chemical properties were tested using t-test for independent samples. For resin-available nitrogen one-way analysis of variance was used to test for significant differences. For litter cover normality was not achieved after appropriate transformation, here the nonparametric Mann-Whitney U-test was used instead.

Temperature and moisture data were analyzed using time series decomposition analysis. Time series decomposition is an approach, for decomposing time series into seasonal fluctuations, trend and random fluctuations (remainder). We used this method to determine differences in trend for temperature and moisture between degraded sites and reference sites. The time series decomposition employed is the one implemented by Cleveland and others (1990) in the function stl() in the stats package in $\mathrm{R}(\mathrm{R}$ Development Core Team 2010). Because of the limited data available (we only used one i-button per site) we did not apply any further statistical analysis.

\section{Results}

\section{Above-Ground Vegetation}

In the kikuyu field we found a dominance of graminoids (90\% alien grass species, mainly Kikuyu and $10 \%$ native grass species), whereas the reference site was characterized by other native shrubs (72\%) mainly Euclea racemosa Murray and Olea exasperata Jacq. In the Acacia thicket, alien trees (54\%), predominantly Acacia saligna interspersed with A. cyclops, and native graminoids (Ficinia sp.) dominated the vegetation. The reference site of the Acacia thicket was dominated by native graminoids $(60 \%)$, mainly Ficinia sp. (20\%), accompanied by ericoids (20\%) and other native shrubs (11\%). Apart from a few native grasses $(17 \%)$ and herbs (9\%) we found no species other than the alien taxa Acacia saligna, Eucalyptus conferruminata, E. cladocalyx, and Paraserianthes lophantha in the Eucalyptus plantation. On the reference site, native graminoids (64\%) dominated the community accompanied by other shrubs (31\%).

Native species richness was significantly lower in the kikuyu field, Acacia thicket and Eucalyptus plantation compared to their natural reference sites. Native plant cover was significantly lower in the kikuyu field and Eucalyptus plantation compared to their reference sites, but did not differ significantly between Acacia thicket and its reference site (Fig. 2). Diversity and evenness were significantly lower in all three degraded sites compared to 


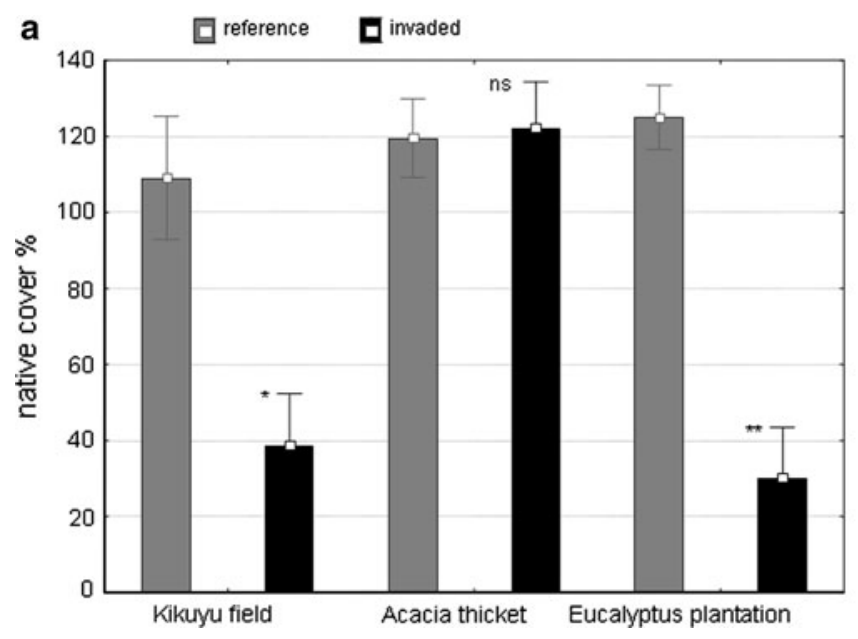

Fig. 2 a Native cover and $\mathbf{b}$ native species richness differences in a kikuyu field, an Acacia thicket and a Eucalyptus plantation in comparison to their intact, natural reference community in Flower Valley, Gansbaai, South Africa, data are means $( \pm \mathrm{SD})$. Differences

their reference sites (kikuyu field $\mathrm{F}(1,4)=94.04$, $P<0.001 ; \mathrm{F}(1,4)=76.6, P<0.001$ respectively; Acacia thicket $\mathrm{F}(1,4)=20.7, \quad P=0.01 ; \quad \mathrm{F}(1,4)=76.6$, $P<0.001$ respectively and Eucalyptus plantation $\mathrm{F}(1$, 4) $=94.281, P<0.001) ; \mathrm{F}(1,4)=38.381, P=0.003$ respectively.

The maximum number of iteration used in the NMDS was 45 . Minimum stress factor obtained was 0.18 which occurred 27 times. Ordination of species composition showed a different composition of dominant species in the kikuyu field and Eucalyptus plantation than in their reference sites, whereas dominant species composition in the Acacia thicket resembled that of its reference site (Fig. 3).

\section{Soil Seed Bank}

In the soil seed bank of the kikuyu site the number of alien species was significantly higher (Mann-Whitney U-test; $P=0.002)$ compared to its reference site, whereas forbs occurred more frequently in the reference site (MannWhitney U-test; $P=0.01$ ). In the Eucalyptus site we found a higher proportion of other shrubs (Mann-Whitney U-test; $P=0.002$ ), whereas the reference site was dominated by graminoids (Mann-Whitney U-test; $P=0.04$ ).

\section{Physical and Chemical Soil Properties}

Litter cover was significantly higher in the Eucalyptus plantation and the Acacia thicket compared to their reference sites and was lowest in the kikuyu field compared to the two other alien-dominated sites (Fig. 4).

In the Acacia site total $\mathrm{N}$ and soil micro-element concentrations $(\mathrm{Na}, \mathrm{Ca}$ and $\mathrm{Mg}$ ) were approximately double b $\quad$ reference $\quad$ invaded

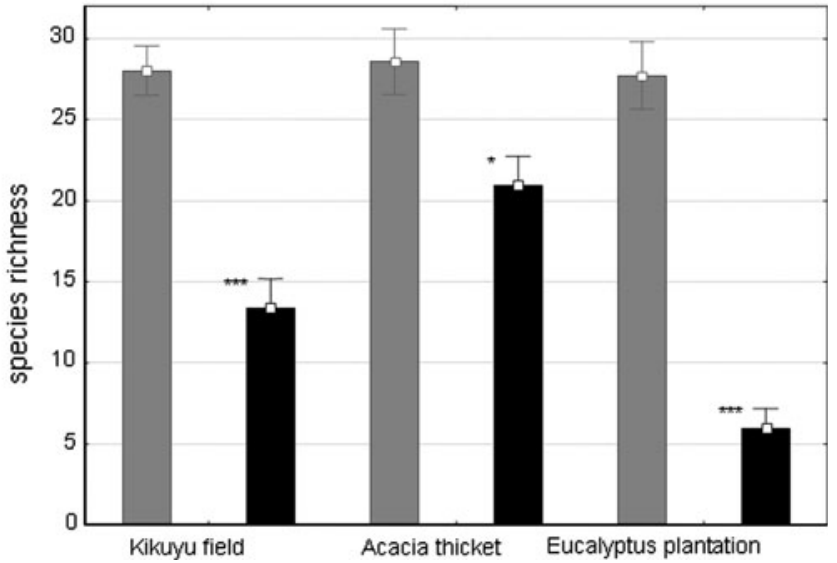

between sites were tested for statistical significance using $t$-test for independent samples. Significance level $* * * p<0.001$, $* * p<0.01$, $* p<0.05, \mathrm{~ns}=$ not significant

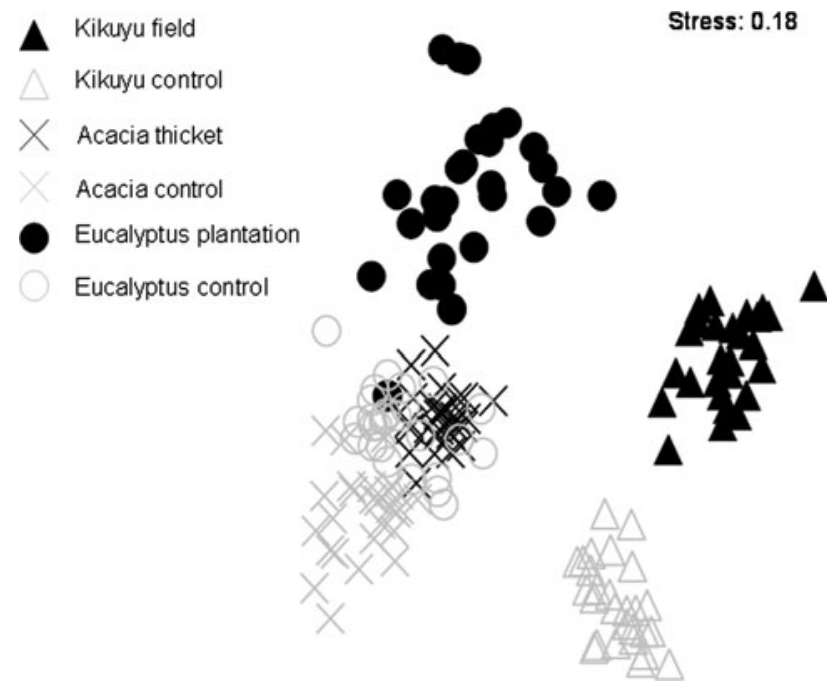

Fig. 3 Ordination analysis (non metric multi dimensional scaling (NMDS)) of vegetation plots in a kikuyu field, an Acacia thicket, and a Eucalyptus plantation and their intact, natural reference community in Flower Valley, Gansbaai, South Africa. Species abundances were used for similarity testing (Bray-Curtis diversity index) after square root transformation. NMDS was running 50 iterations with a minimum stress value of 0.01

those of their reference site. Potassium was the only microelement with a higher concentration in the reference site than in the Acacia site. In the Eucalyptus plantation all micro-element concentrations were double or even three to four times higher than in the reference site. In the kikuyu site and its reference site levels of total $\mathrm{N}$ and $\mathrm{P}$ and $\mathrm{C}$ did not reveal any significant differences. However, $\mathrm{K}$ and $\mathrm{Mg}$ were significantly higher in the reference site (Table 1).

In the kikuyu site no significant difference between resin-available $\mathrm{N}$ in the reference site compared to the 


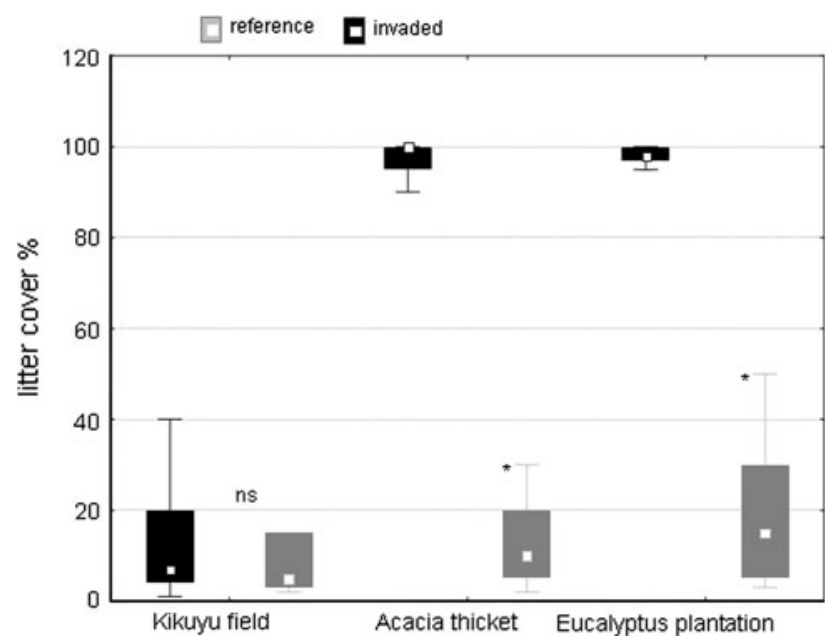

Fig. 4 Litter cover in a kikuyu field, an Acacia thicket, and a Eucalyptus plantation in comparison to their intact, natural reference community in Flower Valley, Gansbaai, South Africa. Data are median with $25 \%$ and $75 \%$ quartile (box) and non-outlier range (whisker). Differences between sites were tested for statistical significance using Mann-Whitney U-test. Significance level $* * * p<0.001, * * p<0.01, * p<0.05, \mathrm{~ns}=$ not significant

alien-dominated site was found in October and December 2007. In February 2008 resin-available $\mathrm{N}$ was significantly higher in the reference site. Resin-available $\mathrm{N}$ in the Acacia thicket did not differ between the alien-dominated site and reference site over the whole study period. In the Eucalyptus plantation resin-available $\mathrm{N}$ was only significantly higher in the degraded site in February 2008 (Fig. 5).

\section{Soil Moisture and Temperature}

The decomposed time series shows differences in trend between temperature and relative moisture in degraded sites and their references sites (Fig. 6).

Temperature in the kikuyu site and its reference site was the same in winter and early spring (August and
September) but the kikuyu site was warmer than its reference site throughout the summer months (October, November and December). In the Acacia site temperatures were constantly lower than in its reference sites, whereas temperatures in the Eucalyptus plantation and its reference site were the same in winter and early spring but lower in the Eucalyptus plantation in summer.

Relative soil moisture was lower in the kikuyu site compared to its reference site during the whole study period. In the Acacia thicket relative soil moisture was lower than in reference site from August to October 2007, between October and December 2007 both sites had similar levels of soil moisture except for November where soil moisture in the Acacia site was lower than in the reference site. In the Eucalyptus plantation relative soil moisture was constantly higher compared to the reference site.

\section{Discussion}

Type and Extent of Ecosystem Degradation

\section{Above-Ground Vegetation and Soil Seed Banks}

We investigated three different degraded sites on South Africa's Agulhas Plain. The three sites had experienced different types of disturbance and were now dominated by different alien plant species. The three types of "degradation" (change from the natural condition) represented on these plots are representative of large areas of degraded land in the region. The aim of our study was to diagnose the type and extent of degradation to determine whether each ecosystem could return to a more natural condition with higher conservation value unaided. Where this seemed unlikely, we sought to provide, on the basis of our findings, practical guidelines for restoration.

Table 1 Soil chemical properties in a kikuyu field, an Acacia thicket and an abandoned Eucalyptus plantation, in matched reference communities measured in May 2007 at Flower Valley, Gansbaai, South Africa

\begin{tabular}{lllllll}
\hline $\begin{array}{l}\text { Nutrients } \\
\mathrm{mg} / \mathrm{kg}\end{array}$ & Kikuyu field & Reference & Acacia thicket & Reference & $\begin{array}{l}\text { Eucalyptus } \\
\text { plantation }\end{array}$ & $\begin{array}{l}\text { Reference } \\
\mathrm{N}\end{array}$ \\
\hline Total P & $22.7(3.25)$ & $21.7(1.23) \mathrm{ns}$ & $13.8(1.87)$ & $11.3(1.36)^{*}$ & $2795.926(708)$ & $1466.67(337.8)^{*}$ \\
$\mathrm{C}$ & $16333.7(5669)$ & $20427(3233) \mathrm{ns}$ & $42693.7(5220.1)$ & $29682.3(5380.6)^{* * *}$ & $34849.6(8914)$ & $23155.6(3933.5)^{* *}$ \\
$\mathrm{Na}$ & $28.2(6.73)$ & $22.0(9.71)^{*}$ & $8.7(1.85)$ & $4.3(0.43)^{*}$ & $13.4(3.88)$ & $3.5(1.78)^{*}$ \\
$\mathrm{~K}$ & $1.8(1.45)$ & $9.8(1.93)^{* * *}$ & $13.0(4.81)$ & $15.6(1.23)^{*}$ & $21.2(6.23)$ & $6.4(2.62)^{*}$ \\
$\mathrm{Ca}$ & $1713.9(117.69)$ & $1468.5(428.52) \mathrm{ns}$ & $418.8(68.91)$ & $207.7(47.74)^{* *}$ & $360.4(101.30)$ & $153.8(31.09)^{* * *}$ \\
$\mathrm{Mg}$ & $98.2(21.95)$ & $52.0(26.04)^{*}$ & $59.5(12.85)$ & $32.9(7.29)^{* *}$ & $57.1(16.51)$ & $16.6(5.09)^{* * *}$ \\
$\mathrm{pH}(\mathrm{KCL})$ & $8.0(0.1)$ & $7.9(0.08) \mathrm{ns}$ & $6.1(0.4)$ & $5.8(0.17) *$ & $6.6(0.68)$ & $5.9(0.33) * * *$ \\
\hline
\end{tabular}

Data are mean $( \pm \mathrm{SD})$. Differences between sites were tested using $t$-test for independent samples. Significance level $* * * p<0.001$, $* * p<0.01, * p<0.05, \mathrm{~ns}=$ not significant 

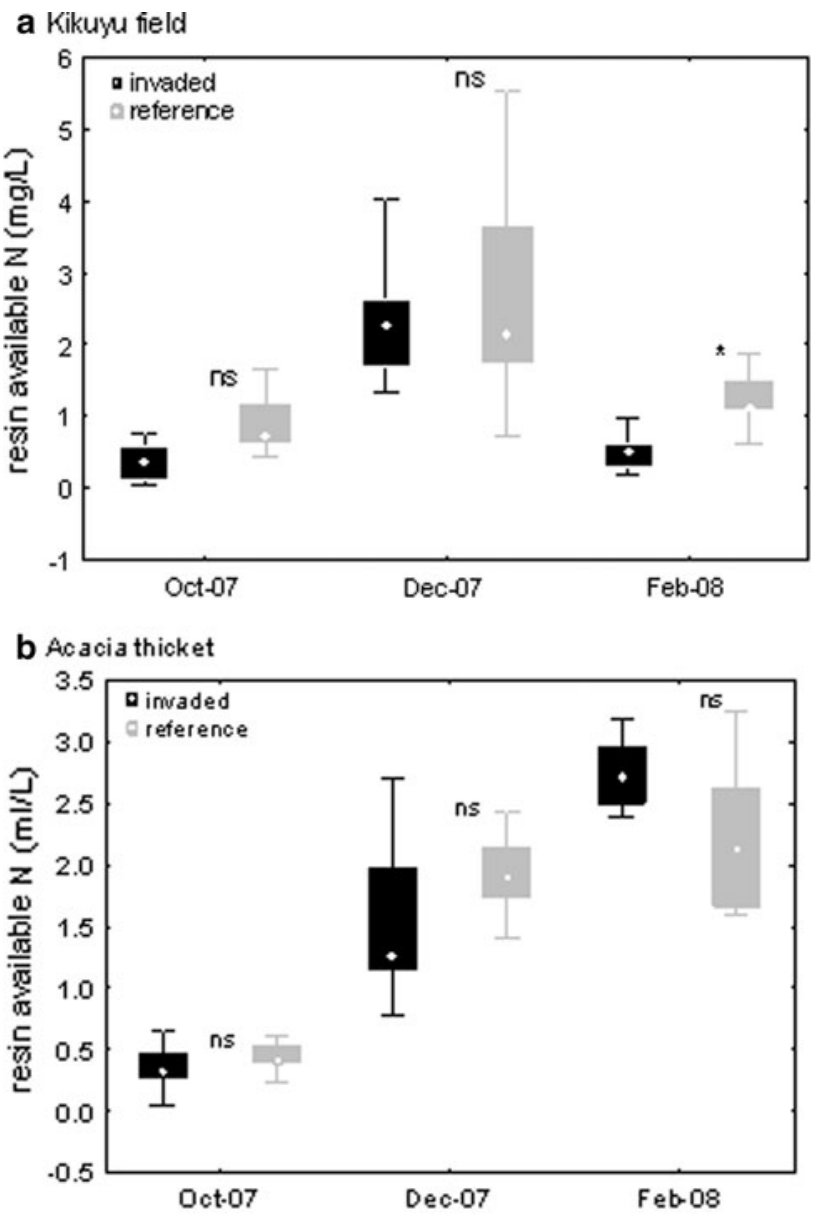

C Eucalyptus plantation

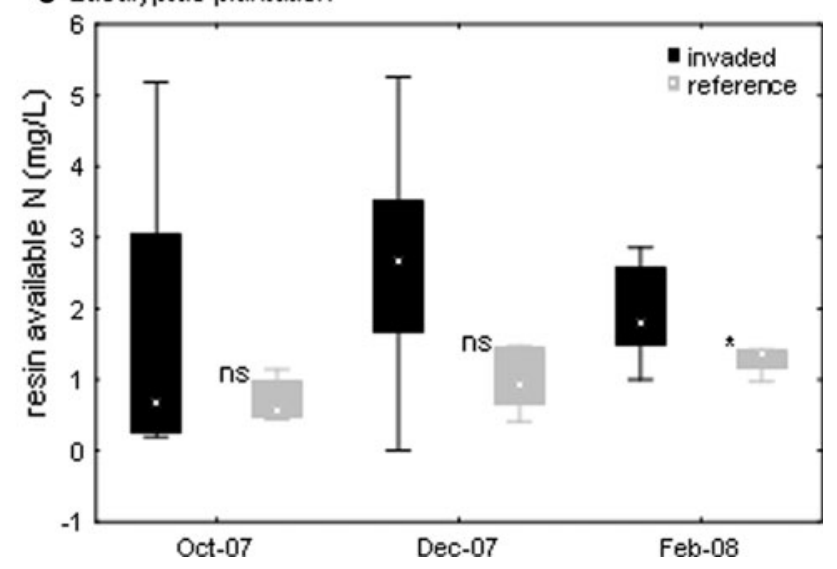

Fig. 5 Concentration of resin available nitrogen in a kikuyu field, an Acacia thicket and a Eucalyptus plantation in comparison to their intact, natural reference community in Flower Valley, Gansbaai, South Africa. Data are median with $25 \%$ and $75 \%$ quartile (box) and non-outlier range (whisker). Differences between sites were tested for statistical significance using one way analysis of variance. Significance level $* * * p<0.001, * * p<0.01, * p<0.05$, ns $=$ not significant

Species richness and cover of native species was remarkably low in the Eucalyptus plantation. Initial disturbance before planting of eucalypts may have contributed to the low species richness, but several other studies have linked different mechanisms associated with alien Eucalyptus species with a reduction in native species diversity (Fernandez-Delgado 1997; Ruthrof and others 2003; Viana and others 2003). There are several possible explanations for this pattern: Many Eucalyptus species exude allelopathic substances which can directly affect the growth of understorey plants where stemflow or litter leachates enter the soil (Del Moral and Muller 1970; May and Ash 1990; Souto and others 1994). It is also well known that alien species compete with native vegetation for limited resources including light, space, nutrients and moisture (Williams and West 2000). There has been no direct study of shade tolerance among fynbos species but community studies indicate that where overstorey shrubs form a dense canopy, understorey species richness is halved (Cowling and Gxaba 1990; Holmes and Cowling 1997). Investigations on the impact of invasive alien trees on water resources in South Africa show that Eucalyptus trees are heavy water users (Le Maitre and others 2002; Forsyth and others 2004). Competition for water is therefore another possible explanation for the reduced native species richness.

Dominance by Pennisetum clandestinum did not trigger any significant changes in soil nutrient levels. Low species richness and native cover in the kikuyu field could be a symptom of the competitive advantage of this grass over fynbos species. Pennisetum clandestinum has been shown elsewhere to form thick impenetrable mats that impede seed germination, survivorship and growth of other species (Cudney and others 1993; Posada and others 2000). The fact that the site was used as agricultural land before invasion definitively also contributes to a competitive advantage of $P$. clandestinum as fynbos plants are extremely sensitive to ploughing (Joubert and others 2009).

Comparatively high native plant cover in the Acacia thicket could be attributed to the fact that the site was only invaded by Acacia species recently, within the last fifteen to twenty years (two fire cycles). Although native plant cover in the Acacia thicket is comparably high, species richness and diversity are lower compared to the reference site. The ordination analysis shows that dominant plant species composition under Acacia resembles the composition of the reference site. We therefore assume that dominant species still manage to survive under Acacia cover. The lower native species richness under Acacia could be ascribed to the fact that less competitive species have already been out-competed. This assumption is supported by findings of Holmes and Cowling (1997) who found that Acacia invasion of fynbos causes community changes, with less competitive species being eliminated first. The decrease of native species richness in Acaciainvaded sites could be attributed to the competitive 
Fig. 6 Difference in trends in a temperature and $\mathbf{b}$ moisture measured from June 2007 to January 2008 in degraded sites (kikuyu site, Acacia site and Eucalyptus site) and reference sites in Flower Valley, Gansbaai, South Africa. To analyze trends time series decomposition analysis was used
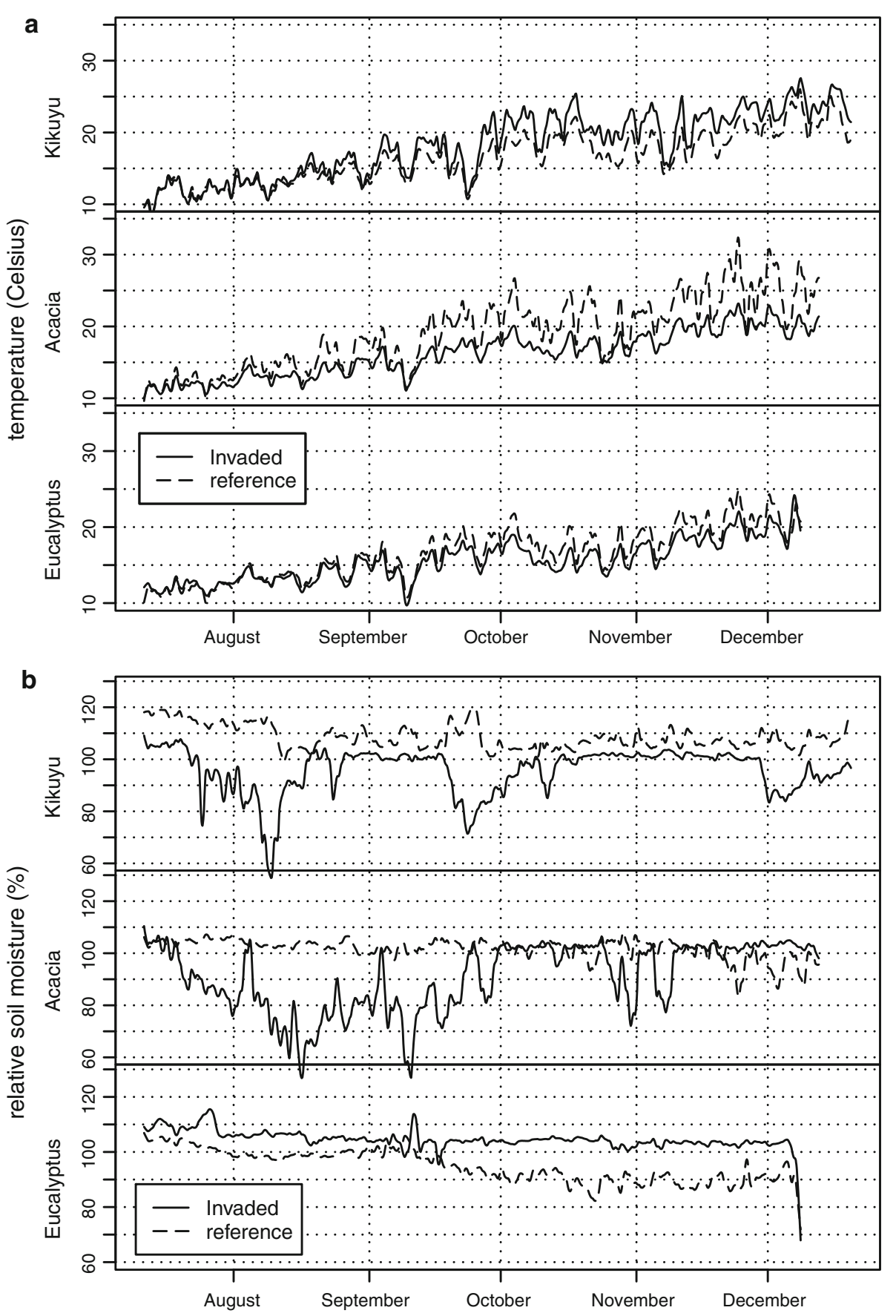

advantage of the nitrogen-fixing Acacia species in low fertile soils (Yelenik and others 2004; Marchante and others 2008; Werner and others 2010), decreased solar radiation, or reduced soil water availability (Musil 1993).

Species richness in the soil seed bank did not differ significantly between alien-dominated and reference sites. This result corresponds with some studies (Wearne and Morgan 2006; Vilà and Gimeno 2007), although most studies on this subject report significant reductions in soil seed banks of native species due to alien invasions (Holmes 2002; Seabloom and others 2003; Turner and others 2008;
Gioria and Osborne 2009). The low species richness in our reference sites could simply reflect the naturally low species richness of seed banks in fynbos communities (Holmes and Richardson 1999).

\section{Alteration of Soil Properties}

Based on results from previous studies (Herr and others 2007; Marchante and others 2008) we expected higher litter cover and higher nutrient levels in the Acacia thicket. The increased rate of $\mathrm{N}$ cycling under Acacia can be 
attributed to their N-fixing capacity (Nakos 1977). Furthermore, Acacia species tend to produce more litter than native fynbos species (Milton 1981; Mitchell and Coley 1987; Witkowski 1991). Higher litterfall rates coupled with higher tissue $\mathrm{N}$ concentrations and a higher decomposition turnover time of Acacia litter results in more $\mathrm{N}$ being returned from above-ground biomass to the soil (Musil and Midgley 1990; Yelenik and others 2004; Marchante and others 2008). Yelenik and others (2004) and Witkowski (1991) showed that increased levels of soil total $\mathrm{N}$ led to consistently higher levels of plant available nitrogen $\left(\mathrm{NH}_{4}{ }^{+}\right.$and $\left.\mathrm{NO}_{3}^{-}\right)$. However, our results do not support their finding, as we did not find significantly higher levels of available nitrogen in the Acacia site compared to its reference site. These results are consistent with findings of Marchante and others (2008). The failure of total $\mathrm{N}$ to translate into available $\mathrm{N}$ could be due to several factors.

Firstly, enhanced levels of plant available nitrogen can lead to higher nutrient uptake, both by native plant species (Hellmann and others 2011) and by Acacia species. Acacia species are characterized by efficient nutrient uptake and can use more of the available nitrogen in the soil than native species (Peperkorn and others 2005; Werner and others 2010). Secondly, the presence of fynbos species on the Acacia site might, despite of high levels of total N, lead to net immobilization of plant available nitrogen, as fynbos systems tend to have very high tannin and carbon levels. High tannin and carbon levels result in a high $\mathrm{C}: \mathrm{N}$ ratio and microbes involved in decomposition compete with the plants for available nitrogen. Similar processes may happen under Acacia as well, as secondary carbon compounds in Acacia litter can create a lag in organic decomposition (Yelenik and others 2007) causing nitrogen to be bound up in the microbial biomass pool leading to high soil total $\mathrm{N}$.

Our hypothesis of low nutrient levels in the Eucalyptus plantation was not supported. Most of the literature on impacts of Eucalyptus species is from large commercial plantations (Alcorn and others 2008; Graciano and others 2008; Walsh and others 2008) whereas our study was conducted in a mixed stand of eucalypts and other tree species. Results of the studies which focus on the impact of Eucalyptus species on soil-mineral status mainly investigated lower nutrient levels in soil under eucalypt plantations (Bargali and others 1993; Tyynela 2001; Turner and Lambert 2008). Low nutrient concentrations in Eucalyptus plantations may be due to low-nutrient litter with high tannin concentrations and slow decomposition rates (BernhardReversat 1996; Guo and Sims 2001). Consequently, large proportions of nutrients may be held in undecomposed litter (Adams and Attiwill 1986). However, Ndaw and others (2009) showed that specific microbial populations develop in the rhizospheres of eucalypts, leading to optimal degradation of plant litter, which could be one explanation for the high nutrient levels in our Eucalyptus plantation. Another explanation could be that the plantation is not a monoculture but a mixed stand including Acacia saligna and Paraserianthes lophantha. Studies in mixed Eucalyptus plantations with $\mathrm{N}$-fixing species show that litter decomposition of Eucalyptus may be enhanced when mixed with more readily decomposable and more nutrient rich litter of $\mathrm{N}$-fixing species (Binkley and others 1992; Briones and Ineson 1996; Turner and Lambert 2008). Furthermore elevated nutrient levels may be ascribed to different traits, such as greater size, higher growth rates and photosynthetic rates, higher leave tissue and litter nutrient concentrations of Eucalyptus trees compared to fynbos shrubs.

The kikuyu field had the same or even lower levels of nutrients than its reference site which could be because moisture at the kikuyu site was constantly lower. Low levels of soil moisture may limit microbial activity. Besides this, resin bags depend on water for transferring ions from the soil to the resin, dry conditions might therefore have reduced the functionality of the bags (Lajtha 1988).

Implications for Restoration of Native Plant Communities and Further Research

Only after the dimensions and degree of ecosystem degradation have been assessed will we be able to predict if the ecosystem will be able to recover unaided after removing the dominant alien plants. Degradation through biological invasion can incorporate biotic changes (e.g., changes in community composition) leading to changes in ecosystem structure (Richardson and others 2007) and/or changes in ecosystem functions (e.g., changes in nutrient cycles). If ecosystem functions are relatively unchanged, removal of alien plants may be the only action required to steer recovery to a target state. If ecosystem functions have been changed, autogenic recovery might have to be facilitated, for example, by re-introducing native species (Gaertner and others 2011).

In the kikuyu site vegetation structure and composition have been changed, however, ecosystem function (i.e., soil nutrient cycling) seems to be unaltered. Here removal of the alien species may be sufficient to initiate ecosystem recovery. However, the rapid regrowth of this highly competitive alien species has to be considered. Therefore managers will certainly have to do several follow-up treatments (such as hand pulling or herbicide application) to reduce secondary invasions.

Changed ecosystem functions (e.g., altered soil-nutrient cycling) may require active restoration after the removal of the alien species. Persistence of soil-nutrient changes caused by invasive species after their removal has been observed in several studies (Maron and Jeffries 2001; Yelenik and others 2007; Marchante and others 2008). This persistence may hamper the restoration of native communities for a long 
period. Firstly, $\mathrm{N}$-fixing species can ameliorate the conditions for their own growth and consequently reinvade a cleared site rapidly (Ehrenfeld 2003; Corbin and D'Antonio 2004). Secondly, the presence of larger nutrient pools may also favor secondary invasion by other weedy species; this has been shown especially in nutrient-poor ecosystems (Maron and Jeffries 2001; Marchante and others 2004; Yelenik and others 2004; Vinton and Goergen 2006). Finally, nutrient enrichment in nutrient-poor ecosystems may also prevent establishment of native species through competition of fast growing weedy species (Maron and Jefferies 1999; Marchante and others 2008). Allelopathy is not regarded as a long-term problem, as allelopathic chemicals are highly soluble and are quickly leached out surface soil by rain (May and Ash 1990). Therefore managers will certainly have to deal with the task of returning soil to pre-invasion nutrient levels to promote native species recolonisation. In fire-prone vegetation like fynbos, the most common practice is burning an area after alien clearing (van Wilgen and others 1994; Holmes and Richardson 1999; Holmes 2008) as large quantities of organic $\mathrm{N}$ can volatilize during a fire (Stock and Lewis 1986). Another strategy could be to add mulch or sawdust with a high C:N ratio to help immobilize the excess of $\mathrm{N}$ in the soil. Although this approach will not change the $\mathrm{N}$ content in the soil, less $\mathrm{N}$ will be available in inorganic form for plant uptake (Zink and Allen 1998; Cione and others 2002; Holmes 2008). Another key to restoring stable, low-nitrate conditions is to plant appropriate native perennial species which have the capacity to extract soil nitrates.

Given the immense extent of degradation on the Agulhas Plain and at the same time considering its high conservation value, cost-efficient and effective methodologies for restoring natural vegetation are urgently required. The longer term outcome of this research program should provide well defined methodologies for restoring natural fynbos (thereby improving the conservation status and increasing commercial value for landowners) under a variety of soil and alien species scenarios.

Acknowledgments We are grateful to Patricia Holmes for very helpful discussions in experiment implementation and for her ongoing support during the project and to Brigitte Braschler and Rainer M. Krug for statistical advice. Financial support was provided by the Flower Valley Conservation Trust and the Agulhas Biodiversity initiative. We acknowledge support from the DST-NRF Centre of Excellence for Invasion Biology (MG, DMR) and the Hans Sigrist Foundation (DMR).

\section{References}

Adams MA, Attiwill PM (1986) Nutrient cycling and nitrogen mineralization in eucalypt forests of south-eastern Australia. 1. Nutrient cycling and nitrogen turnover. Plant and Soil 92:319-339
Alcorn PJ, Bauhus J, Thomas DS, James RN, Smith RGB, Nicotra AB (2008) Photosynthetic response to green crown pruning in young plantation-grown Eucalyptus pilularis and E. cloeziana. Forest Ecology and Management 255:3827-3838

Bargali SS, Singh RP, Joshi M (1993) Changes in soil characteristics in eucalypt plantations replacing natural broad-leaved forests. Journal of Vegetation Science 4:25-28

Bernhard-Reversat F (1996) Nitrogen cycling in tree plantations grown on a poor sandy savanna soil in Congo. Applied Soil Ecology 4:161-172

Binkley D, Dunkin KA, Debell D, Ryan MG (1992) Production and nutrient cycling in mixed plantations of Eucalyptus and Albizia in Hawaii. Forest Science 38:393-408

Briones MJI, Ineson P (1996) Decomposition of Eucalyptus leaves in litter mixtures. Soil Biology \& Biochemistry 28:1381-1388

Brooks ML, D'Antonio CM, Richardson DM, Grace JB, Keeley JE, DiTomaso JM, Hobbs RJ, Pellant M, Pyke D (2004) Effects of invasive alien plants on fire regimes. Bioscience 54:677-688

Brown NAC, Botha PA (2004) Smoke seed germination studies and a guide to seed propagation of plants from the major families of the Cape Floristic Region, South Africa. South African Journal of Botany 70:559-581

Brudvig LA (2011) The restoration of biodiversity: where has research been und where does it need to go? American Journal of Botany 98:1-10

Chabrerie O, Loinard J, Perrin S, Saguez R, Decocq G (2010) Impact of Prunus serotina invasion on understory functional diversity in a European temperate forest. Biological Invasions 12:1891-1907

Cione NK, Padgett PE, Allen EB (2002) Restoration of a native shrubland impacted by exotic grasses, frequent fire, and nitrogen deposition in southern California. Restoration Ecology 10:376-384

Clarke KR, Warwick RM (2001) Change in marine communities: an approach to statistical analysis and interpretation. PRIMER-E Ltd, Plymouth

Cleveland RB, Cleveland WS, McRae JE, Terpenning I (1990) A seasonal-trend decomposition procedure based on Loess. Journal of Official Statistics 6:3-73

Corbin JD, D'Antonio CM (2004) Effects of exotic species on soil nitrogen cycling: implications for restoration. Weed Technology 18:1464-1467

Cowling RM, Gxaba T (1990) Effects of a fynbos overstorey shrub on understorey community structure: implications for the maintenance of community wide species richness. South African Journal of Ecology 1:1-7

Cudney DW, Downer JA, Gibeault VA, Henry JM, Reints JS (1993) Kikuyugrass (Pennisetum clandestinum) management in turf. Weed Technology 7:180-184

Del Moral R, Muller CH (1970) The allelopathic effects of Eucalyptus camaldulensis. American Midland Naturalist 83:254-282

Ehrenfeld JG (2003) Effects of exotic plant invasions on soil nutrient cycling processes. Ecosystems 6:503-523

Fernandez-Delgado C (1997) Conservation management of a European natural area: Donana National Park, Spain. In: Meffe GK, Carroll CR (eds) Principles of conservation biology. Sinauer Associates Inc, Sunderland, Massachusetts, pp 458-467

Forsyth GG, Richardson DM, Brown PJ, van Wilgen BW (2004) A rapid assessment of the invasive status of Eucalyptus species in two South African provinces. South African Journal of Science 100:75-77

Gaertner M, Den Breeyen A, Hui C, Richardson DM (2009) Impacts of alien plant invasions on species richness in Mediterraneantype ecosystems: A meta-analysis. Progress in Physical Geography 33:319-338

Gaertner M, Holmes PM, Richardson DM (2011) Biological invasions, resilience and restoration. In: Van Andel J, Aronson 
J (eds) Restoration Ecology: the New Frontier. Blackwell Publishing LTD, Oxford, England

Gibson DJ (1986) Spatial and temporal heterogeneity in soil nutrient supply measured using in situ ion-exchange resin bags. Plant and Soil 96:445-450

Gioria M, Osborne B (2009) Assessing the impact of plant invasions on soil seed bank communities: use of univariate and multivariate statistical approaches. Journal of Vegetation Science 20:547-556

Goldblatt P, Manning J (2000) Cape plants. A conspectus of the Cape flora of South Africa. Strelitzia 9:1-744

Graciano C, Goya JF, Arturi M, Perez C, Frangi JL (2008) Fertilization in a fourth rotation Eucalyptus grandis plantation with minimal management. Journal of Sustainable Forestry 26:155-169

Guo LB, Sims REH (2001) Effects of light, temperature, water and meat works effluent irrigation on eucalypt leaf litter decomposition under controlled environmental conditions. Applied Soil Ecology 17:229-237

Gurevitch J, Padilla DK (2004) Are invasive species a major cause of extinctions? Trends in Ecology \& Evolution 19:470-474

Hejda M, Pyšek P, Jarosik V (2009) Impact of invasive plants on the species richness, diversity and composition of invaded communities. Journal of Ecology 97:393-403

Hellmann C, Sutter R, Rascher KG, Máguas C, Correia O, Werner C (2011) Impact of an exotic N2-fixing Acacia on composition and $\mathrm{N}$ status of a native Mediterranean community. Acta Oecologica $37: 43-50$

Herr C, Chapuis-Lardy L, Dassonville N, Vanderhoeven S, Meerts P (2007) Seasonal effect of the exotic invasive plant Solidago gigantea on soil $\mathrm{pH}$ and $\mathrm{P}$ fractions. Journal of Plant Nutrition and Soil Science-Zeitschrift für Pflanzenernährung und Bodenkunde 170:729-738

Hobbs RJ (2007) Setting effective and realistic restoration goals: Key directions for research. Restoration Ecology 15:354-357

Holmes PM (2002) Depth distribution and composition of seed-banks in alien-invaded and uninvaded fynbos vegetation. Austral Ecology 27:110-120

Holmes PM (2008) Optimal ground preparation treatments for restoring lowland Sand Fynbos vegetation on old fields. South African Journal of Botany 74:33-40

Holmes PM, Cowling RM (1997) The effects of invasion by Acacia saligna on the guild structure and regeneration capabilities of South African fynbos shrublands. Journal of Applied Ecology 34:317-332

Holmes PM, Richardson DM (1999) Protocols for the restoration based on recruitment dynamics, community structure and ecosystem function: perspectives from South African fynbos. Restoration Ecology 7:215-230

Joubert L, Esler KJ, Privett SDJ (2009) The effect of ploughing and augmenting natural vegetation with commercial fynbos species on the biodiversity of Overberg Sandstone fynbos on the Agulhas Plain, South Africa. South African Journal of Botany 75:526-531

Lajtha K (1988) The use of ion-exchange resin bags for measuring nutrient availability in an arid ecosystem. Plant and Soil 105:105-111

Le Maitre DC, van Wilgen BW, Gelderblom CM, Bailey C, Chapman RA, Nel JA (2002) Invasive alien trees and water resources in South Africa: case studies of the costs and benefits of management. Forest Ecology and Management 160:143-159

MacDougall SA, Turkington R (2005) Are invasive species the drivers or passengers of change in degraded ecosystems? Ecology 86:42-55

Marchante HS, Marchante EM, Buscardo E, Maia J, Freitas H (2004) Recovery potential of dune ecosystems invaded by an exotic
Acacia species (Acacia longifolia). Weed Technology 18:1427-1433

Marchante E, Kjøller A, Struwe S, Freitas H (2007) Soil microbial activity in dune ecosystems in Portugal invaded by Acacia longifolia. In: Tokarska-Guzik B, Brock JH, Brundu G, Child L, Daehler CC, Pysek P (eds) Plant invasions: human perception, ecological impacts and management. Backhuys Publishers, Leiden, The Netherlands, pp 247-257

Marchante E, Kjoller A, Struwe S, Freitas H (2008) Short- and longterm impacts of Acacia longifolia invasion on the belowground processes of a Mediterranean coastal dune ecosystem. Applied Soil Ecology 40:210-217

Maron JL, Jefferies RL (1999) Bush lupine mortality, altered resource availability, and alternative vegetation states. Ecology 80:443-454

Maron JL, Jeffries RL (2001) Restoring enriched grasslands: effects of mowing on species richness, productivity, and nitrogen retention. Ecological Applications 11:1088-1100

May EF, Ash JE (1990) An assessment of the allelopathic potential of Eucalyptus. Australian Journal of Botany 38:245-254

Meiners SJ, Pickett STA, Cadenasso ML (2002) Exotic plant invasions over 40 Years of old field successions: community patterns and associations. Ecography 25:215-223

Milton SJ (1981) Litterfall of the exotic acacias in the south-western Cape South African Journal of Botany 47:147-155

Milton SJ (2004) Grasses as invasive alien plants in South Africa. South African Journal of Science 100:69-75

Mitchell DT, Coley PGF (1987) Litter production and decomposition from shrubs of Protea repens growing on sand-plain lowland and mountain fynbos, south-western Cape. South African Journal of Botany 53:25-31

Mucina L, Rutherford MC (2006) The vegetation of South Africa, Lesotho and Swaziland. South African National Biodiversity Institute, Pretoria

Musil CF (1993) Effect of invasive Australian Acacias on the regeneration, growth and nutrient chemistry of South-African lowland fynbos. Journal of Applied Ecology 30:361-372

Musil CF, Midgley GF (1990) The relative impact of invasive Australian acacias, fire and season on the soil chemical status of a sand plain lowland fynbos community. South African Journal of Botany 56:419-427

Nakos G (1977) Acetylene-reduction (N2-Fixation) by Nodules of Acacia cyanophylla. Soil Biology \& Biochemistry 9:131-133

Ndaw SM, Gama-Rodrigues AC, Gama-Rodrigues EF, Sales KRN, Rosado AS (2009) Relationships between bacterial diversity, microbial biomass, and litter quality in soils under different plant covers in northern Rio de Janeiro State, Brazil. Canadian Journal of Microbiology 55:1089-1095

Peperkorn R, Werner C, Beyschlag W (2005) Phenotypic plasticity of an invasive acacia versus two native Mediterranean species. Functional Plant Biology 32:933-944

Plieninger T, Gaertner M (2011) Harnessing degraded lands for biodiversity conservation. Journal for Nature Conservation 19:18-23

Posada JM, Aide TM, Cavelier J (2000) Cattle and weedy shrubs as restoration tools of tropical montane rainforest. Restoration Ecology 8:370-379

Privett SDJ, Heydenrych BJ, Cowling RM (2002) Putting biodiversity to business on the Agulhas Plain. In: Pierce SM, Cowling RM, Sandwith T, MacKinnon K (eds) Mainstreaming biodiversity in development. Case studies from South Africa. World Bank, Washington DC, pp 101-116

Rebelo AG (1992) Preservation of biotic diversity. In: Cowling RM (ed) The ecology of fynbos: nutrients, fire and diversity. Oxford University Press, Cape Town, pp 309-344

Richardson DM (1998) Forestry trees as invasive aliens. Conservation Biology 12:18-26 
Richardson DM, Holmes PM, Esler KJ, Galatowitsch SM, Stromberg JC, Kirkman SP, Pyšek P, Hobbs RJ (2007) Riparian vegetation: degradation, alien plant invasions, and restoration prospects. Diversity and Distributions 13:126-139

Rouget M, Richardson DM, Cowling RM, Lloyd JW, Lombard AT (2003) Current patterns of habitat transformation and future threats to biodiversity in terrestrial ecosystems of the Cape Floristic Region, South Africa. Biological Conservation 112:63-85

Ruthrof KX, Loneragan WA, Yates CJ (2003) Comparative population dynamics of Eucalyptus cladocalyx in its native habitat and as an invasive species in an urban bushland in south-western Australia. Diversity and Distributions 9:469-483

Seabloom EW, Borer ET, Boucher VL, Burton RS, Cottingham KL, Goldwasser L, Gram WK, Kendall BE, Micheli F (2003) Competition, seed limitation, disturbance, and reestablishment of California native annual forbs. Ecological Applications 13:575-592

Seabloom EW, Williams JW, Slayback D, Stoms DM, Viers JH, Dobson AP (2006) Human impacts, plant invasion, and imperiled, plant species in California. Ecological Applications $16: 1338-1350$

Souto XC, Gonzalez L, Reigosa MJ (1994) Comparative analysis of allelopathic effects produced by 4 forestry species during decomposition process in their soils in Galicia (NW Spain). Journal of Chemical Ecology 20:3005-3015

Stock WD, Lewis OAM (1986) Atmospheric input of nitrogen to a coastal fynbos ecosystem of the south-western Cape Province, South Africa. South African Journal of Botany 52:273-276

Turner J, Lambert MJ (2008) Nutrient cycling in age sequences of two Eucalyptus plantation species. Forest Ecology and Management 255:1701-1712

Turner PJ, Scott JK, Spafford H (2008) The ecological barriers to the recovery of bridal creeper (Asparagus asparagoides (L.) Druce) infested sites: impacts on vegetation and the potential increase in other exotic species. Austral Ecology 33:713-722

Tyynela TM (2001) Species diversity in Eucalyptus camaldulensis woodlots and miombo woodland in Northeastern Zimbabwe. New Forests 22:239-257

Underwood EC, Viers JH, Klausmeyer KR, Cox RL, Shaw MR (2009) Threats and biodiversity in the mediterranean biome. Diversity and Distributions 15:188-197 van Wilgen BW, Richardson DM, Seydack A (1994) Managing fynbos for biodiversity: constraints and options in a fire-prone environment. South African Journal of Science 90:322-329

Viana SM, David VA, Fushita AT, Garcia C, Oliveira FF, Nakajo JC, Santos LRB, Batalha MA (2003) Diversity of the cerrado woody component in regeneration process under influence of Eucalyptus in Sao Carlos, Sao Paulo, Brazil. Arquivos do Instituto Biologico (Sao Paulo) 70:76

Vilà M, Gimeno I (2007) Does invasion by an alien plant species affect the soil seed bank? Journal of Vegetation Science 18:423-430

Vinton MA, Goergen EM (2006) Plant-soil feedbacks contribute to the persistence of Bromus inermis in tallgrass prairie. Ecosystems 9:967-976

Walsh PG, Barton CVM, Haywood A (2008) Growth and carbon sequestration rates at age ten years of some Eucalypt species in the low- to medium-rainfall areas of New South Wales, Australia. Australian Forestry 71:70-77

Wearne LJ, Morgan JW (2006) Shrub invasion into subalpine vegetation: implications for restoration of the native ecosystem. Plant Ecology 183:361-376

Werner C, Zumkier U, Beyschlag W, Maguas C (2010) High competitiveness of a resource demanding invasive acacia under low resource supply. Plant Ecology 206:83-96

Williams JA, West CJ (2000) Environmental weeds in Australia and New Zealand: issues and approaches to management. Austral Ecology 25:425-444

Witkowski ETF (1991) Effects of invasive alien Acacias on nutrient cycling in the coastal lowlands of the Cape Fynbos. Journal of Applied Ecology 28:1-15

Yelenik SG, Stock WD, Richardson DM (2004) Ecosystem level impacts of invasive Acacia saligna in the South African fynbos. Restoration Ecology 12:44-51

Yelenik SG, Stock WD, Richardson DM (2007) Functional group identity does not predict invader impacts: differential effects of nitrogen-fixing exotic plants on ecosystem function. Biological Invasions 9:117-125

Zink TA, Allen MF (1998) The effects of organic amendments on the restoration of a disturbed coastal sage scrub habitat. Restoration Ecology 6:52-58 